\title{
ANALISIS PENGARUH PLANNED BEHAVIORAL LIP CREAM KOSMETIK WARDAH TERHADAP PURCHASE INTENTION DAN CONSUMER BUYING BEHAVIOR SECARA ONLINE
}

\author{
Aulya Rahman Baihaqi', Zulkarnain², Gatot Wijayanto ${ }^{3}$ \\ Pascasarjana Universitas Riau \\ aulyarbaihaqi471@gmail.com
}

\begin{abstract}
The Muslim population in Indonesia and in the world has experienced growth and is followed by an increase in their income in every Muslim-majority country. With this increase, the demand for halal products in Indonesia and in other Muslim-majority countries has increased. Although the market for halal cosmetic products is large, most of the cosmetics and other personal care products are made by non-Muslim producers in non-Muslim countries, which can lead to disputes about the halalness of their ingredients. One of the halal cosmetic brands circulating in Indonesia is Wardah. This study aims to obtain clearer information about how Wardah's Lip Cream planned behavioral, towards purchase intention and consumer buying behavior of students on Wardah cosmetic products. The data analysis technique was carried out with a structural equation modeling (SEM) program to adjust the data to the TPB model. From the results of data analysis and hypothesis testing that has been carried out, it is found that there is an influence on the attitude variable, subjective norms of perceived behavioral control on purchase intention. And there is also an influence on the purchase intention variable and the behavior control perception variable on consumer purchasing behavior.
\end{abstract}

Keywords: Consumer Behavior, Cosmetics, Halal Products.

\section{ABSTRAK}

Penduduk muslim di Indonesia maupun di dunia mengalami pertumbuhan serta diikuti dengan peningkatan pendapatan mereka di setiap negara-negara mayoritas beragama Islam. Dengan adanya peningkatan ini, maka permintaan terhadap produk halal baik di Indonesia maupun di negara mayoritas muslim lainnya meningkat. Meskipun pasar untuk produk kosmetik halal adalah besar, sebagian besar kosmetik dan produk perawatan pribadi lainnya dibuat oleh produsen non-Muslim di negara-negara non-Muslim, yang dapat menyebabkan perselisihan tentang hal-hal yang halal dari bahan-bahan mereka. Salah satu merk kosmetik halal yang beredar di Indonesia ialah Wardah. Penelitian ini bertujuan untuk memperoleh informasi yang lebih jelas mengenai bagaimana planned behavioral kosmetik lip cream Wardah, terhadap purchase intention dan consumer buying behavior mahasiswa pada produk kosmetik wardah. Teknik analisis data yang dilakukan dengan program pemodelan persamaan struktural (SEM) untuk menyesuaikan data dengan model TPB. Dari hasil analisis data dan pengujian hipotesis yang telah dilakukan diperoleh bahwa, terdapat pengaruh pada variabel sikap, norma subyektif persepsi kontrol perilaku terhadap minat beli. Serta terdapat juga pengaruh pada variabel minat beli dan variabel persepsi kontrol perilaku terhadap perilaku pembelian konsumen.

Kata kunci: Kosmetik, Perilaku Konsumen, Produk Halal. 
PENDAHULUAN

Penduduk muslim diIndonesia maupun di dunia mengalami pertumbuhan serta diikuti dengan peningkatan pendapatan mereka di setiap negara-negara mayoritas beragama Islam. Dengan adanya peningkatan ini, maka permintaan terhadap produk halal baik di Indonesia maupun di negara mayoritas muslim lainnya meningkat. Jika dahulu pasar terhadap produk halal ini dianggap biasa saja dan tidak terlalu menguntungkan, tapi saat ini pasar produk halal digunakan beberapa negara yang kemudian dapat meningkatkan devisa negara tersebut. Halal Industry Development Corporation memperkirakan penjualan barang dan jasa halal ini menyentuh Usd 2,3 triliun. Kemudian permintaan produk halal ini tidak hanya dari negara muslim untuk mengkonsumsinya, seperti negara Thailand, Jepang dsb.

Menurut Lada (2009) kata "halal" asal mulanya dari bahasa arabic yang diartikan diperbolehkan dan merupakan kewajiban yang mengatur semua aspek kehidupan umat muslim diseluruh dunia. Bagi masyarakat muslim menggunakan produk halal merupakan suatu hal yang wajib dan harus dilaksanakan. Seseorang apabila memiliki religiusitas yang baik, perilaku konsumsinya mengarah sesuai dengan ajaran agamanya. Pada kasus ini adalah konsumen yang beragama islam, ia tidak akan menggunakan barang yang memiliki unsur yang diharamkan oleh agama islam seperti darah, daging babi, minuman beralkohol, hewan bertaring, hewan yang diperbolehkan dikonsumsi tetapi ketika menyembelih tidak dengan ajaran Islam atau tidak dengan membaca basmallah, dan lainnya.

Menurut Ajzen (2005) keyakinan pada individu akan norma, dan pengaruh lingkungan disekitarnya dan motivasi agar mengikuti norma itu disebut juga dengan norma subjektif. Sejalan dengan syariat Islam, umat muslim menginginkan produk yang dikonsumsi nya bermanfaat, aman dan halal sehingga konsumen yang beragama islam merasa tenang lahir dan batin saat menggunakan kosmetik yang digunakannya sehari-hari (Norafni et al., 2015).

Kosmetik ialah barang yang sering digunakan oleh konsumen perempuan dalam kehidupannya sehari-hari. Dengan menggunakan kosmetik akan dapat menambah kepercayaan diri konsumennya. Tak heran bila kosmetik sekarang merupakan salah satu produk yang wajib digunakan bagi para konsumen wanita dari berbagai kelas sosial.

Kosmetik yang beredar di Indonesia sekarang banyak import dari luar negeri seperti dari negara Korea, China, Thailand dll. Di mana produk yang berasal dari luar negeri ini belum dapat dipastikan kehalalan produknya. Yang mana bahan baku dari kosmetik itu masih menggunakan yang dilarang agama, seperti enzim dari hewan babi dan sebagainya. 
Meskipun penjualan untuk produk kosmetik halal adalah besar, banyak kosmetik dan produk skin care lainnya di produksi oleh pihak nonMuslim di negara sebagian besar bukan beragama Islam, yang mana menyebabkan perbedaan tentang kehalalan dari dasar bahan mereka. Sehingga, sektor farmasi maupun kosmetik telah menjadi subjek pengawasanyang lebih besar oleh para peneliti Muslim karena kecurigan bahwasanya merek luar negeri banyak menggunakan saripati yang dihasilkan dari hewan babi maupun alkohol yang digunakan menjadi pengawet,sehingga menimbulkan banyak kecurigaan terhadap merk-merk ini di lingkungan Muslim.

Sigma Research Indonesia mengadakan penelitian kepada 1.200 wanita di Indonesia dengan segmen usia 15-55 tahun. Perilaku konsumen yang tertinggi presentasenya adalah kecocokan formula pada kulit wajah 79,4\%. Ini menunjukkan bahwa, konsumen cenderung memilih sebuah produk kosmetik berdasarkan kecocokkan formula pada kulit wajahnya. Kemudian diikuti oleh kosmetik yang awet 67,4\%, memiliki bahan yang ringan 62,2\%. Produk yang tahan lama di wajah sangat disukai konsumen, karena konsumen tidak perlu melakukan make up kembali dikarenakan make up nya hilang.

Sedangkan pertimbangan pembelian kosmetik halal sendiri masih 58,3\% dari 1200 konsumen perempuan. Ini berarti kesadaran akan halal suatu produk kosmetik masih di abaikan oleh konsumen perempuan. Pengaruh harga 51,5\%, hanya beberapa wanita mempertimbangkan harga untuk kecantikan kulitnya. Kemudian kemasan yang mudah dibawa (praktis) sebesar 40,2\%. Dan tampilan kemasan, berbahan organik, mengikuti tren, dan iklan hanya dibawah 30\% peresentase yang dipilih oleh konsumen wanita.

Menurut Lada et al. (2009) sikap seseorang itu merupakan hasil evaluasi yang dihadapi seseorang itu baik positif maupun negatif untuk melakukan perilaku. Menurut Ajzen (2005) bahwa untuk mewujudkan perilaku itu adanya kontrol perilaku baik itu sulit maupun mudah menurut persepsi individu itu sendiri (persepsi kontrol perilaku).

Salah satu merk kosmetik halal yang beredar di Indonesia ialah Wardah. Kosmetik Wardah adalah produk kecantikan dan produk perawatan kulit buatan lokal yang aman dan memiliki kualitas tinggi dengan meenciptakan ragam kegunaan untuk berbagai macam kondisi atau keluhan kulit. Produk Wardah sendiri sudah dikenal di masyarakat Indonesia, karena produk wardah ini melakukan pengiklanan dengan model artis muslimah yang terkenal di masyarakat. Produk wardah telah tertanam di pikiran masyarakat Indonesia sebagai salah satu produk kosmetik yang halal. 
Selain mengeluarkan produk perawatan kulit, kosmetik Wardah juga mengeluarkan produk lip cream. Produk lip cream ini berguna sebagai pewarna bibir. Lip cream berbeda dengan lipstik, karena lipstik produk pewarna bibir yang berbentuk padat, sedangkan lip cream berbentuk cair atau krim. Peneliti memilih produk lip cream wardah sebagai objek penelitian ini karena lip cream wardah ini memiliki peresntase pertumbuhan penjualan yang terus berada pada peringkat pertama di Top Brand Index.

Menurut penelitian yang dilakukan oleh Lada (2009) "Predicting intention to choose halal products using theory of reasoned action" sikap dan norma subjektif seseorang dengan produk halal yang ia gunakan berpengaruh terhadap minat beli seseorang itu. Penelitian ini bertujuan untuk memperoleh informasi yang lebih jelas mengenai bagaimana planned behavioral kosmetik lip cream Wardah, terhadap purchase intention dan consumer buying behavior mahasiswa pada produk kosmetik wardah.

\section{TINJAUAN LITERATUR}

\section{Theory Planned Behavior}

Theory Planned Behavior (Ajzen, 1991) merupakan pengembangan dari theory reasoned action (TRA) teori yang diciptakan Ajzen dan Fishbein pada tahun 1985, yang dibuat perlu oleh ketidakmampuan teori sebelumnya untuk menjelaskan perilaku di mana individu tidak memiliki kontrol penuh untuk memenuhi kehendaknya. Kontrol terhadap perilaku mewakili sejauh mana suatu perilaku dapat di lakukan sesua dengan keinginan hati (Blackwell, 2006). Perilaku yang dilakukan secara tidak sadar tidak dapat diterangkan pada teori ini.

Pada theory planned behavioral menerangkan bahwa sesuatu yang akan dilakukan oleh seseorang dari sebuah prilaku tertentu dipilih oleh keinginan nya untuk melaksanakan perilaku tersebut. Pada theory planned behavioral, sikap terhadap prilaku sasaran dan norma subjektif tentang terlibatnya dalam perilaku diperkirakan untuk mempengaruhi minat perilaku pembelian kosmetik halal, dan theory planned behavioral termasuk dirasakan kontrol perilaku lebih terlibat dalam prilaku sebagai faktor yang mana mempengaruhi minat dan prilaku pembelian.

Sikap terhadap perilaku merupakan suatu hal positif maupun negatif untuk melaksanakan prilaku itu dan kontrol untuk melakukan suatu prilaku yang dirasakan individu diinformasikan oleh keyakinan tentang kemampuan individu dari peluang dan sumberdaya yang akan digunakan dalam sebuah perilaku (Ajzen, 1991). 
Gambar 1 Theory Planned Behavior

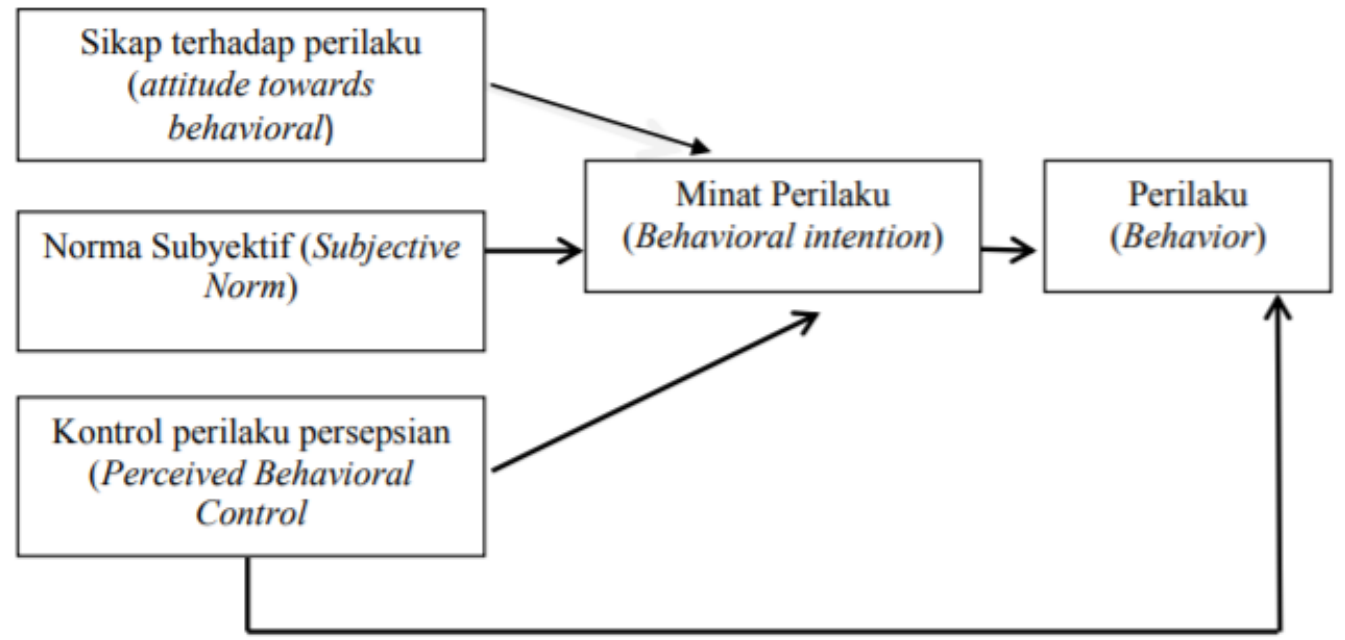

Sumber: Ajzen (2015)

Menurut Ajzen (2005), ia menjelaskan sikap terhadap perilaku ini ditentukan oleh kepercayaan individu tentang imbal hasil yang akan diperolehnya dari suatu prilaku dan scara singkat di sebut keyakinan suatu perilaku.Keyakinan berhubungan dengan penilaian subyektif seseorang terhadap lingkungan sekitarnya, pemahaman seseorang tentang diri maupun lingkungan sekitar nya, dilaksanakan dengan cara menghubungkan prilaku tersebut dengan berbagai keuntungan maupun kerugian yang kemungkinan akan dialami jika seseorang melaksanakan atau tidak melaksanakannya.

Alam dan Sayuti (2011) menyatakan bahwa sikap memiliki pengaruh yang signifikan dan positif terhadap minat pembelian makanan halal. Ajzen (2005) menjelaskan norma subyektif yaitu fungsi yang membahas tentang kesetujuan dan atau ketidak setujuan individu maupun kelompok yang berpengaruh bagi seseorang terhadap suatu perilaku. Azmi (2010) menerangkan bahwa konsumen Muslim mungkin termotivasi untuk menggunakan produk kosmetik Halal karena produk kosmetik Halal sesuai dengan syariat Islam. Penelitian mereka membuktikkan bahwa norma subyektif harus dibenarkan sebagai indikator penting konsumen Muslim untuk menggunakan produk kosmetik halal.

Menurut Ajzen(2005) Presepsi kontrol perilaku atau disebut juga dengan kontrol perilaku adalah presepsi seseorang tentang gampang ataupun sulitnya mewujudkan suatu perilaku tertentu. Untuk menerangkan tentang persepsi kontrol perilaku ini, ia membedakan dengan pusat kendali pada diri sendiri.

Minat pembelian merupakan suatu hal yang mewakili seseorang yang memiliki kesempatan, kemungkinan, plan ataupun brsedia untuk melakukan pembelian produk ataupun 
jasa dimasa yang akan datang. Peningkatan minat pembelian ini juga disebut dengan peningkatan kemungkinan pembelian. Para peneliti dapat juga memakai minat beli merupakan faktor penting untuk memprediksi perilaku konsumen itu. Ketika seseorang telah mempunyai minat untuk membeli yang positif ini bentuk komitmen untuk sebuah merk, bahwa merk itu positif dan baik. Hal inilah yang mendorong pembelian dan pada akhirnya akan dilakukan oleh orang-orang (Schiffman, 2007).

Menurut Kottler (2005), Perilaku pembelian konsumen adalah bagaimana individu, kelompok dan organisasi untuk memilih, membeli, menggunakan dan pembuangan produk, layanan, ide atau pengalaman untuk memenuhi permintaan konsumen. Sedangkan menurut Shiffman \& Kanuk (2010) Kinerja dalam pencarian, pembelian, penggunaan dan mengevaluasi perilaku produk dan layanan untuk memenuhi permintaan

Berdasarkan penelitian yang dilakukan oleh Sihombing (2004), perilaku pembelian konsumen diartikan sebagai: yang pertama segala sesuatu yang dilakukan oleh seseorang, kemudian yang kedua adanya perubahan baik materi maupun bukan materi yng di sebabkan langsung oleh individu, perilaku juga merupakan hasil dari proses mental seseorang. Sikap dan minat ialah contoh beberapa variabel yang mempengaruhi perilaku. Kemudian mnurut Sihombing (2004), pada prilaku dapat dibedakan menjadi kegiatan, tindakan dan hubungan. tindakan merupakan prgerakan dari fisik dalaam waktu jangka pendek. Kegiatan diartikan sebagai tindakan-tindakan yang dilakukan beberapa kali dalam waktu jangka panjang.

Menurut Ajzen dan Fishbein (1980) mendefinisikan perilaku pembelian yang sebenarnya sebagai keinginan individu untuk membeli barang-barang manufaktur tertentu atau jasa. minat membeli diukur berdasarkan studi sebelumnya. Davies dan Wright (1994) menjelaskan bahwa perilaku pembelian berasal dari yang memadai kesadaran terhadap produk.

\section{Hipotesis}

$\mathrm{H}_{1}$ : Sikap berpengaruh positif signifikan terhadap Minat Beli.

$\mathrm{H}_{2}$ : Norma Subyektif berpengaruh positif signifikan terhadap Minat Beli.

$\mathrm{H}_{3}$ : Persepsi Kontrol Perilaku berpengaruh positif signifikan terhadap Minat Beli.

$\mathrm{H}_{4}$ : Minat Beli berpengaruh positif signifikan terhadap Perilaku Pembelian Konsumen.

$\mathrm{H}_{5}$ : Persepsi Kontrol Perilaku berpengaruh positif signifikan terhadap Perilaku Pembelian Konsumen. 
Tabel 1 Penelitian Terdahulu

\begin{tabular}{|c|c|c|c|c|}
\hline No & Nama, Tahun, Judul & Analisis & Variabel & Keterangan \\
\hline 1 & $\begin{array}{l}\text { Shah Alam \& Mohamed } \\
\text { Sayuti (2011) } \\
\text { Applying the Theory of } \\
\text { Planned Behavior (TPB) } \\
\text { in halal food purchasing }\end{array}$ & SEM & $\begin{array}{l}\text { - Sikap } \\
\text { - Norma } \\
\text { Subyektif } \\
\text {-Persepsi Kontrol } \\
\text { Perilaku } \\
\text { - Minat Beli }\end{array}$ & $\begin{array}{l}\text { - Sikap berpengaruh positif } \\
\text { signifikan terhadap Minat Beli } \\
\text { - Norma Subyektif berpengaruh } \\
\text { positif signifikan terhadap Minat } \\
\text { Beli } \\
\text { - Persepsi Kontrol Perilaku } \\
\text { berpengaruh positif signifikan }\end{array}$ \\
\hline 2 & $\begin{array}{l}\text { Abd Rahman } \text { et al. } \\
(2015) \\
\text { Consumers and Halal } \\
\text { cosmetic products: } \\
\text { knowledge, religiosity, } \\
\text { attitude and intention }\end{array}$ & SEM & $\begin{array}{l}\text { - Sikap } \\
\text {-Pengetahuan } \\
\text { - Religousity } \\
\text { - Minat Beli }\end{array}$ & $\begin{array}{l}\text { - Sikap berpengaruh positif } \\
\text { signifikan terhadap Minat Beli } \\
\text { - Pengetahuan tidak berpengaruh } \\
\text { terhadap Sikap } \\
\text { - Religousity berpengaruh positif } \\
\text { signifikan terhadap Sikap }\end{array}$ \\
\hline 3 & $\begin{array}{l}\text { Afendi et al. (2014) } \\
\text { Determinants of Halal } \\
\text { Purchase Intention: Case } \\
\text { in Perlis. }\end{array}$ & $\begin{array}{c}\text { Regresi } \\
\text { Berganda }\end{array}$ & $\begin{array}{l}\text { - Sikap } \\
\text { - Norma } \\
\text { Subyektif } \\
\text {-Persepsi Kontrol } \\
\text { Perilaku } \\
\text { - Minat Beli }\end{array}$ & $\begin{array}{l}\text { - Sikap berpengaruh positif } \\
\text { signifikan terhadap Minat Beli } \\
\text { - Norma Subyektif berpengaruh } \\
\text { positif signifikan terhadap Minat } \\
\text { Beli } \\
\text {-Persepsi Kontrol Perilaku } \\
\text { berpengaruh positif signifikan } \\
\text { terhadap Minat Beli }\end{array}$ \\
\hline 4 & $\begin{array}{l}\text { Khalek \& Ismail (2015) } \\
\text { Why Are We Eating } \\
\text { Halal-Using the Theory } \\
\text { of Planned Behavior in } \\
\text { Predicting Halal Food } \\
\text { Consumption among } \\
\text { Generation Y in } \\
\text { Malaysia }\end{array}$ & $\begin{array}{c}\text { Regresi } \\
\text { Berganda }\end{array}$ & $\begin{array}{l}\text { - Sikap } \\
\text { - Norma } \\
\text { Subyektif } \\
\text {-Persepsi Kontrol } \\
\text { Perilaku } \\
\text { - Minat Beli }\end{array}$ & $\begin{array}{l}\text { - Sikap berpengaruh positif } \\
\text { signifikan terhadap Minat Beli } \\
\text { - Norma Subyektif berpengaruh } \\
\text { positif signifikan terhadap Minat } \\
\text { Beli } \\
\text { - Persepsi Kontrol Perilaku } \\
\text { berpengaruh positif signifikan } \\
\text { terhadap Minat Beli }\end{array}$ \\
\hline 5 & $\begin{array}{l}\text { Nursalwani et al. (2017) } \\
\text { The Effect of Attitude, } \\
\text { Subjective Norm and } \\
\text { Perceived Behaviour } \\
\text { Control Towards } \\
\text { Intention of Muslim } \\
\text { Youth at Public } \\
\text { Universities in Kelantan } \\
\text { to Consume Halal } \\
\text { Labelled Chocolate Bar } \\
\text { Product }\end{array}$ & $\begin{array}{c}\text { Regresi } \\
\text { Berganda }\end{array}$ & $\begin{array}{l}\text { - Sikap } \\
\text { - Norma } \\
\text { Subyektif } \\
\text {-Persepsi Kontrol } \\
\text { Perilaku } \\
\text { - Minat Beli }\end{array}$ & $\begin{array}{l}\text { - Sikap berpengaruh positif } \\
\text { signifikan terhadap Minat Beli } \\
\text { - Norma Subyektif berpengaruh } \\
\text { positif signifikan terhadap Minat } \\
\text { Beli } \\
\text { - Persepsi Kontrol Perilaku tidak } \\
\text { berpengaruh terhadap Minat Beli }\end{array}$ \\
\hline
\end{tabular}

\section{METODE PENELITIAN}

Penelitian ini dilakukan di Universitas Islam Riau (UIR). Jenis data yang digunakan pada penelitian ini adalah data primer yang diperoleh secara langsung dari kuesioner yang disebarkan pada mahasiswi UIR. Adapun populasi mahasiswi di Universitas Islam Riau 
sebanyak 9.593 perempuan. Dalam penelitian ini besarnya sampel ditetapkan dengan rumus Slovin. Berdasarkan rumus Slovin tersebut, maka diperolah besarnya sampel sebagai berikut:

$$
\begin{aligned}
& \mathrm{n}=\frac{9.593}{1+9.593(0.1)^{2}} \\
& \mathrm{n}=\frac{9593}{96,93} \\
& \mathrm{n}=98,96 \text { (dibulatkan menjadi } 100 \text { responden) }
\end{aligned}
$$

Teknik analisis data yang dilakukan dengan program pemodelan persamaan struktural (SEM) untuk menyesuaikan data dengan model TPB. SEM adalah teknik multivariat yang menggabungkan aspek regresi dan analisis faktor untuk menilai serangkaian hubungan dependen secara bersamaan yang tidak mungkin menggunakan teknik multivariat lainnya (Hair et al., 2014). Teknik analisis yang dipergunakan untuk menganalisis data

\begin{tabular}{|c|c|c|c|}
\hline Variabel & Definisi Variabel & Indikator & Skala \\
\hline Sikap & $\begin{array}{l}\text { Sikap terhadap perilaku ini ditentukan oleh } \\
\text { kepercayaan individu tentang imbal hasil } \\
\text { yang akan diperolehnya dari suatu prilaku } \\
\text { dan scara singkat di sebut keyakinan suatu } \\
\text { perilaku (Ajzen, 2005). }\end{array}$ & $\begin{array}{l}\text { 1. Perasaan suka } \\
\text { 2. Kepercayaan } \\
\text { 3. Label halal adalah hal penting } \\
\text { 4. Kepercayaan terhadap } \\
\text { kehalalan }\end{array}$ & Ordinal \\
\hline $\begin{array}{l}\text { Norma } \\
\text { Subyektif }\end{array}$ & $\begin{array}{l}\text { Norma subyektif yaitu fungsi yang } \\
\text { membahas tentang kesetujuan dan atau } \\
\text { ketidak setujuan individu maupun } \\
\text { kelompok yang berpengaruh bagi } \\
\text { seseorang terhadap suatu perilaku } \\
\text { (Ajzen, 2005). }\end{array}$ & $\begin{array}{l}\text { 1. Pengaruh orang orang penting } \\
\text { 2. Pengaruh keluarga } \\
\text { 3. Ajakan teman-teman }\end{array}$ & Ordinal \\
\hline $\begin{array}{l}\text { Persepsi } \\
\text { Kontrol } \\
\text { Perilaku }\end{array}$ & $\begin{array}{l}\text { Presepsi kontrol perilaku atau disebut juga } \\
\text { dengan kontrol perilaku adalah presepsi } \\
\text { seseorang tentang gampang ataupun } \\
\text { sulitnya mewujudkan suatu perilaku } \\
\text { tertentu. (Ajzen, 1991). }\end{array}$ & $\begin{array}{l}\text { 1. Kemampuan untuk membeli } \\
\text { 2. Pengetahuan untuk membeli } \\
\text { 3. Kemampuan untuk } \\
\text { menggunakan } \\
\text { 4. } \begin{array}{l}\text { Pengetahuan } \\
\text { menggunakan }\end{array} \\
\end{array}$ & Ordinal \\
\hline Minat Beli & $\begin{array}{l}\text { Minat pembelian merupakan suatu hal yang } \\
\text { mewakili seseorang yang memiliki } \\
\text { kesempatan, kemungkinan, plan ataupun } \\
\text { brsedia untuk melakukan pembelian } \\
\text { produk ataupun jasa dimasa yang akan } \\
\text { datang (Schiffman,2007). }\end{array}$ & $\begin{array}{l}\text { 1. Tertarik mencari informasi } \\
\text { tentang produk } \\
\text { 2. Pertimbangan membeli } \\
\text { 3. Tertarik mencoba } \\
\text { 4. Ingin tahu produk } \\
\text { 5. Ingin punya produk }\end{array}$ & Ordinal \\
\hline $\begin{array}{l}\text { Perilaku } \\
\text { Pembelian } \\
\text { Konsumen }\end{array}$ & $\begin{array}{l}\text { Perilaku pembelian yang sebenarnya } \\
\text { sebagai keinginan individu untuk membeli } \\
\text { barang-barang manufaktur tertentu atau } \\
\text { jasa (Ajzen dan Fishbein, 1980). }\end{array}$ & $\begin{array}{l}\text { 1. Kemudahan dalam pembelian } \\
\text { 2. Ketika melakukan pembelian } \\
\text { masukan teman dan keluarga } \\
\text { penting bagi saya } \\
\text { 3. Memiliki pengetahuan dan }\end{array}$ & Ordinal \\
\hline
\end{tabular}
adalah SEM (Structural Equation Model) dengan menggunakan AMOS.

\section{Tabel 2 Operasional Variabel Penelitian}




\begin{tabular}{|l|l|l|l|}
\hline & & $\begin{array}{l}\text { melihat tidak ada kendala } \\
\text { Jika terjadi masalah saya akan } \\
\text { mencari alternatif }\end{array}$ & \\
\hline
\end{tabular}

\section{HASIL PENELITIAN DAN PEMBAHASAN}

Statistik data responden tujuannya ada memberikan informasi (gambaran) secara umum responden yang menjadi sampel dalam penlitian ini. Responden penelitian ini sebanyak 100 responden yang akan dibagi menjadi tiga bagian berdasarkan usia, fakultas dan semester. Berikut adalah penyajian data mengenai profil responden yang didapat dalam penelitian ini:

Tabel 3 Karakteristik Responden Berdasarkan Usia

\begin{tabular}{lll}
\hline \multicolumn{1}{c}{ Usia } & \multicolumn{1}{c}{ Frekuensi } & \multicolumn{1}{c}{ Persentase } \\
\hline 20-22 Tahun & 95 & 95,0 \\
\hline$>$ 23 Tahun & 5 & 5,0 \\
\hline Total & $\mathbf{1 0 0}$ & $\mathbf{1 0 0 , 0}$ \\
\hline
\end{tabular}

Sumber: Data olahan kuesioner (2021)

Tabel 4 Karakteristik Responden Berdasarkan Fakultas

\begin{tabular}{lll}
\hline \multicolumn{1}{c}{ Fakultas } & Frekuensi & Persentase \\
\hline Fakultas Ekonomi \& Bisnis & 80 & 80 \\
\hline Fakultas Hukum & 7 & 7 \\
\hline Fakultas Ilmu Budaya & 2 & 2 \\
\hline $\begin{array}{l}\text { Fakultas Ilmu Sosial Ilmu } \\
\text { Politik }\end{array}$ & 8 & 8 \\
\hline Fakultas Psikologi & 3 & 3 \\
\hline Total & $\mathbf{1 0 0}$ & $\mathbf{1 0 0}$ \\
\hline
\end{tabular}

Sumber: Data olahan kuesioner (2021)

Tabel 5 Karakteristik Responden Berdasarkan Fakultas

\begin{tabular}{ccc}
\hline Semester & Frekuensi & Persentase \\
\hline 2 & 9 & 9 \\
\hline 4 & 28 & 28 \\
\hline 6 & 53 & 53 \\
\hline 8 & 9 & 9 \\
\hline 10 & 1 & 1 \\
\hline Total & $\mathbf{1 0 0}$ & $\mathbf{1 0 0}$ \\
\hline
\end{tabular}

Sumber: Data olahan kuesioner (2021)

\section{Pengujian Kualitas Data}

\section{Gambar jalur hubungan kausalitas}

Model teori yang sudah dibangun pada hipotesis penelitian ini akan dituangkan pada gambar dalam satu digram alur. Diagram alur atau path-diagram tersebut akan 
mempermudah peneliti melihat hubungan-hubbungan kausalitas yang akan diuji. Dibawah ini adalah path-diagram pada penelitian ini:

\section{Gambar 2 Diagram Konseptual}

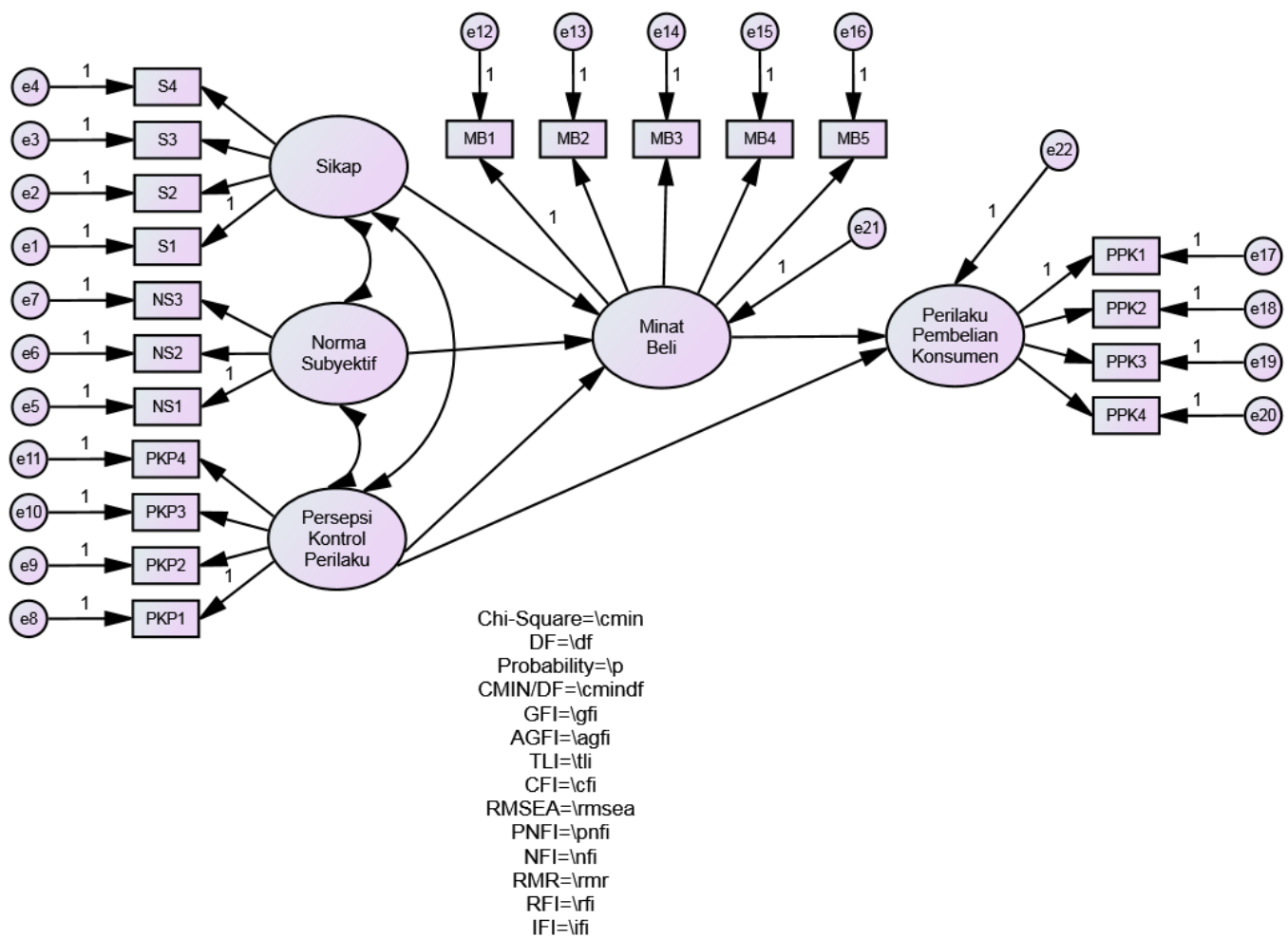

Pada gambar diagram konseptual diatas dapat dilihat bahwa semua variabel bersifat refleksif karena semua arah panahnya dari variabel ke indikator. Model jalur terdiri dari 2 (dua) sub struktur, dijabarkan melalui persamaan-persamaan berikut:

Model 1:

Minat beli $=$ Sikap + Norma Subyektif + Persepsi Kontrol Perilaku $+\mathrm{e}_{1}$

Model 2:

Perilaku Pembelian Konsumen $=$ Persepsi Kontrol Perilaku + Minat Beli $+\mathrm{e}_{2}$

\section{Confirmatory Factor Analysis (CFA)}

Untuk menentukan suatu indikator yang digunakan untuk mengukur validitas suatu variabel laten digunakan faktor loading sebagai indikator. Faktor loading sebesar 0.5 atau lebih besar digunakan untuk mengindikasikan bahwa suatu indikator valid. Confirmatory factor analysis bertujuan utuk menguji undimensionalitas dari dimensi-dmensi pembentuk 
masing-masing variable laten. Hasil Confirmatory factor analysis dari masing-masing model selanjut nyaakan di bahas.

\section{Analisis Konfirmatori Faktor-1}

Pengujian kemaknan pada indikator yang terekstraktion dalam membentuk variable laten, dapat dihasilkan dari nilai standarized loading-factor dari masing dimensi. Pada pengujian jika dihasilkan nilai yang sngat significant maka hal ini menunjukkan bahwa indikator tersebut cukup baik untuk terekstraktion membentuk variable laten. Hasil berikut merupakan pengujian kemaknan masing-masing indikator dalam membentuk variable laten.

Tabel 6 Regression Weight pada Analisis Faktor Konfirmatori -1

Tabel Regression Weight Pada Analisis Faktor Konfirmatori - 1

\begin{tabular}{|c|c|c|c|c|c|c|}
\hline & & Estimate & S.E. & C.R. & $P$ & Label \\
\hline S1 & $<--\mathrm{S}$ & 1,000 & & & & \\
\hline S2 & $<---\quad S$ & 1,168 & ,227 & 5,155 & $* * *$ & par_1 \\
\hline S3 & $<---\quad S$ & 1,453 & ,255 & 5,692 & $* * *$ & par_2 \\
\hline S4 & $<---\quad S$ & 1,256 & ,222 & 5,650 & $* * *$ & par_3 \\
\hline NS1 & $<---\quad$ NS & 1,000 & & & & \\
\hline NS2 & $<---\quad$ NS & 1,082 & ,194 & 5,568 & $* * *$ & par_4 \\
\hline NS3 & $<---\quad$ NS & 1,034 & , 189 & 5,466 & $* * *$ & par_5 \\
\hline PKP1 & $<---$ PKP & 1,000 & & & & \\
\hline PKP2 & $<---$ PKP & ,806 & ,070 & 11,451 & $* * *$ & par_6 \\
\hline PKP3 & $<---$ PKP & ,879 & ,067 & 13,125 & $* * *$ & par_7 \\
\hline PKP4 & $<--$ PKP & ,729 & ,084 & 8,652 & $* * *$ & par_8 \\
\hline
\end{tabular}

Sumber: Data olahan Output Amos (2021)

Analisis faktor ini menunjukan nilai pngujian dari masing-msing pembentuk suatu konstruk.Hasil menjelaskkan bahwa pada tiap indikator-indiktor pmbentuk masing-masing variabel laten menunjukkan hasil baik, ialah nilai dengan C.R di atas 1,96 atau dengan probabiltas yang lebih kecil dari 0,05. Selain itu nilai loading-factor (standarized estimate) dari semua indikator berada lebih besar dari 0,5. Berdasarkan hasil ini, maka dpat dikatakkan bahwa indikator-indikator pembentuk variable laten eksogen telah menunjukkan unidimensionalitas atau valid. Selanjutnya berdasarkan Confirmatory factor analysis ini, maka model penelitian ini dapat digunakan untuk menganalisis selanjutnya tanpa adanya modifikasi atau penyesuaian-penyesuaian. 


\section{Analisis Konfirmatori Faktor-2}

Analisis faktor ini menunjukan nilai pngujian dari masing-msing pembentuk suatu konstruk.Hasil menjelaskkan bahwa pada tiap indikator-indiktor pmbentuk masing-masing variabel laten menunjukkan hasil baik, ialah nilai dengan C.R di atas 1,96 atau dengan probabiltas yang lebih kecil dari 0,05. Selain itu nilai loading-factor (standarized estimate) dari semua indikator berada lebih besar dari 0,5. Berdasarkan hasil ini, maka dpat dikatakkan bahwa indikator-indikator pembentuk variable laten eksogen telah menunjukkan unidimensionalitas atau valid. Selanjutnya berdasarkan Confirmatory factor analysis ini, maka model penelitian ini dapat digunakan untuk menganalisis selanjutnya tanpa adanya modifikasi atau penyesuaian-penyesuaian.

Tabel 7 Regression Weight Pada Analisis Faktor Konfirmatori - 2

\begin{tabular}{|c|c|c|c|c|c|c|c|}
\hline & & & $\begin{array}{r}\text { Es } \\
\text { timate }\end{array}$ & .E. & .R. & $\mathrm{P}$ & Lab \\
\hline B1 & --- & B & $\begin{array}{r}1,00 \\
0\end{array}$ & & & & \\
\hline B2 & --- & B & ,803 & $115^{\prime}$ & $\begin{array}{r}6 \\
, 977\end{array}$ & $\begin{array}{r}* * \\
*\end{array}$ & par_9 \\
\hline B3 & --- & B & ,655 & $115^{\prime}$ & $\begin{array}{r}5 \\
, 719\end{array}$ & $\begin{array}{l}* * \\
* 0\end{array}$ & par_1 \\
\hline B4 & --- & B & ,878 & 118 & $\begin{array}{r}7 \\
, 473\end{array}$ & $\begin{array}{l}* * \\
* 1 \\
*\end{array}$ & par_1 \\
\hline B5 & --- & B & ,872 & 124 & $\begin{array}{r}7 \\
, 005\end{array}$ & $\begin{array}{l}* * \\
* 2\end{array}$ & par_1 \\
\hline PK1 & --- & PK & $\begin{array}{r}1,00 \\
0\end{array}$ & & & & \\
\hline PK2 & --- & PK & ,777 & 127 & $\begin{array}{r}6 \\
, 111\end{array}$ & $\begin{array}{l}* * \\
* 3\end{array}$ & par_1 \\
\hline PK3 & --- & PK & 908 & 119 & $\begin{array}{r}7 \\
, 627\end{array}$ & $\begin{array}{l}* * \\
* 4\end{array}$ & par_1 \\
\hline PK4 & --- & PK & ,958 & $130^{\prime}$ & $\begin{array}{r}7 \\
, 361 \\
\end{array}$ & $\begin{array}{l}* * \\
* 5 \\
\end{array}$ & par_1 \\
\hline
\end{tabular}

Sumber: Data olahan Output Amos (2021)

\section{Uji Reliabilitas dan Average Variance Extracted}

Pendekatan untuk melakukan penilaian measurement model ialah mengukur composite reability dan variance extracted untuk setiap konstruk. Reability merupakan ukuran internal konsistensi indokator pada suatu konstruk. Hasil reabilitas yang tinggi menunjukkan keyakinan bahwa indikator individu semua konsisten dengan pengukurannya. Tingkat reliabilitas yang diterima secara umum ialah lebih besar dari 0.70 . 


$$
\begin{aligned}
\text { Construct Reliability } & =\frac{\left(\sum \text { std loading }\right)^{2}}{\left(\sum \text { std loading }\right)^{2}+\sum \varepsilon j} \\
\text { Variance extracted } & =\frac{\sum \text { std loading }}{\sum \text { std loading }}+\sum \varepsilon j
\end{aligned}
$$

Setelah dilakukannya uji validitas maka yang harus dilakukan selanjutnya adalah menghitung ataupun menganilisis reliabilitas variabel penelitian. Setelah dilakukan perhitungan menggunakan Ms. Excel dengan rumus perhitungan di atas, maka didapatkan hasil dari nilai construct reliability dan variance extracted. Tabel 8 menunjukkan hasil construct-reliability dan average variance extracted pada masing-masing variabel penelitian. Diketahui bahwa variabel laten memiliki nilai koefisien construct-reliability yang lebih besar dari atau samadengan nilai kritis $(\mathrm{CR} \geq 0,7)$ dan nilai variance-extracted lebih dari nilai kritis $(0,5)$. Hal ini menunjukkan bahwa ke dua variabel eksogen tersebut memiliki tingkat reliabilitas yang baik.

Tabel 8 Hasil Uji Reliabilitas dan AVE Variabel Eksogen

\begin{tabular}{|c|c|c|c|c|c|c|}
\hline \multicolumn{2}{|c|}{ CFA } & $\begin{array}{l}\text { Loading } \\
\text { Factor }\end{array}$ & Kriteria & Kesimpulan & C.R & AVE \\
\hline \multirow{4}{*}{ Sikap } & S1 & 0,586 & 0,5 & Valid & \multirow{4}{*}{0,819} & \multirow{4}{*}{0,535} \\
\hline & S2 & 0,689 & 0,5 & Valid & & \\
\hline & S3 & 0,836 & 0,5 & Valid & & \\
\hline & S4 & 0,789 & 0,5 & Valid & & \\
\hline \multirow{3}{*}{$\begin{array}{c}\text { Norma } \\
\text { Subyektif }\end{array}$} & NS1 & 0,746 & 0,5 & Valid & \multirow{3}{*}{0,759} & \multirow{3}{*}{0,513} \\
\hline & NS2 & 0,741 & 0,5 & Valid & & \\
\hline & NS3 & 0,658 & 0,5 & Valid & & \\
\hline \multirow{4}{*}{$\begin{array}{l}\text { Persepsi } \\
\text { Kontrol } \\
\text { Perilaku }\end{array}$} & PKP1 & 0,907 & 0,5 & Valid & \multirow{4}{*}{0,907} & \multirow{4}{*}{0,710} \\
\hline & PKP2 & 0,842 & 0,5 & Valid & & \\
\hline & PKP3 & 0,887 & 0,5 & Valid & & \\
\hline & PKP4 & 0,722 & 0,5 & Valid & & \\
\hline
\end{tabular}

Tabel Hasil Uji Reliabilitas dan AVE Variabel Eksogen

Sumber: Data olahan Output Amos (2021)

\begin{tabular}{|c|c|c|c|c|c|c|}
\hline \multicolumn{2}{|c|}{ CFA } & $\begin{array}{l}\text { Lo } \\
\text { Factor }\end{array}$ & riteria $^{\mathbf{K}}$ & $\begin{array}{c}\text { Kes } \\
\text { impulan }\end{array}$ & . $\mathbf{R}$ & VE \\
\hline \multirow{3}{*}{$\begin{array}{r}\mathrm{M} \\
\text { inat Beli }\end{array}$} & B1 & $15^{0,7}$ & $\begin{array}{rr} & 0 \\
, 5 & \\
\end{array}$ & $\mathrm{~d}$ Vali & \multirow{3}{*}{, 854} & \multirow{3}{*}{, 542} \\
\hline & B2 & $45^{0,7}$ &, 5 & $\mathrm{~d}^{\text {Vali }}$ & & \\
\hline & & 0,5 & 0 & Vali & & \\
\hline
\end{tabular}

Tabel 9 Hasil Uji Reliabilitas dan AVE Variabel Endogen 


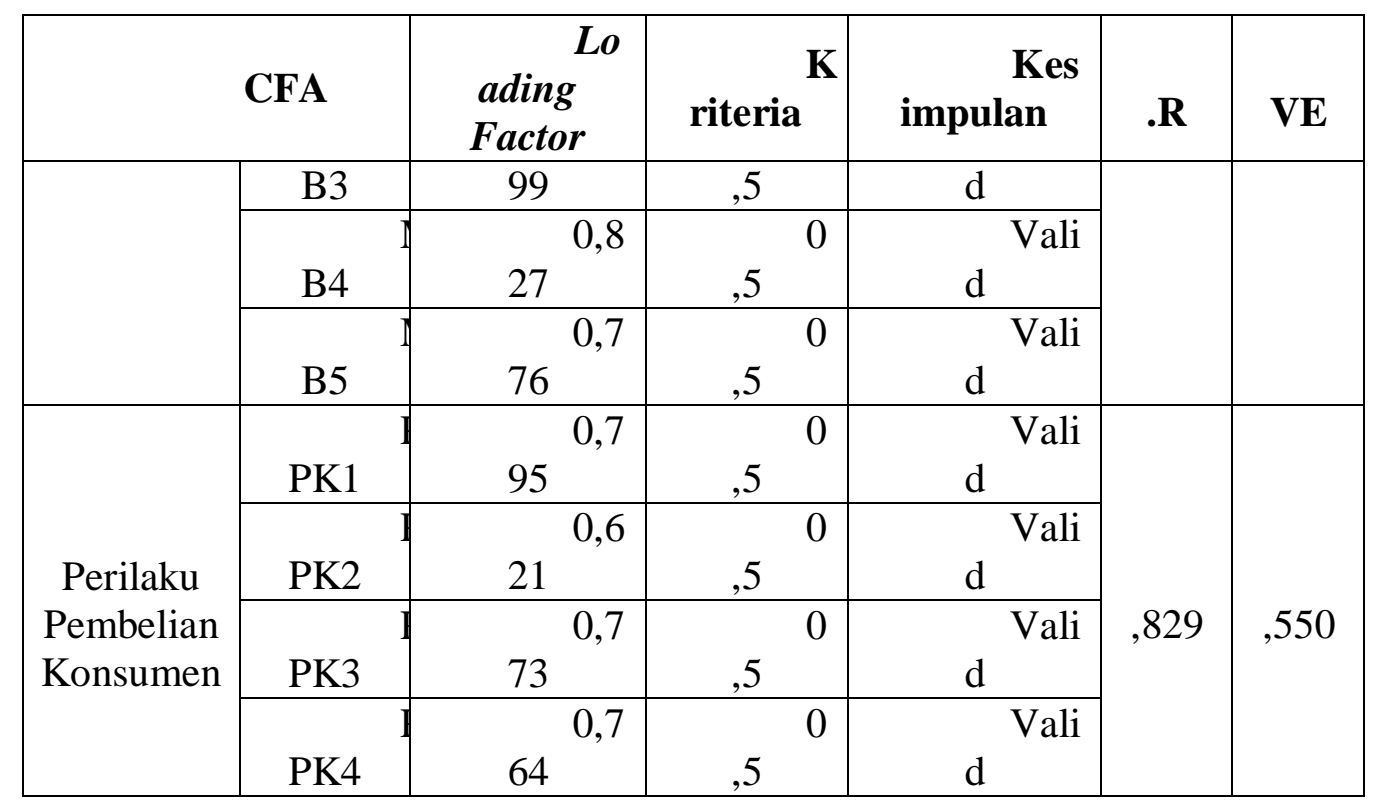

Sumber: Data olahan Output Amos (2021)

Tabel di atas menunjukkan hasil construct-reliability dan variance-extracted pada masing-masing variabel penelitian. Diketahui bahwa variabel laten memiliki nilai koefisien construct-reliability yang lebih besar dari atau sama dengan nilai kritis $(\mathrm{CR} \geq 0,7)$ dan nilai variance extracted lebih dari nilai kritis $(0,5)$. Hal ini menunjukkan bahwa ke dua variabel endogen tersebut memiliki tingkat reliabilitas yang baik.

\section{Pengujian Model Struktural}

\section{Analisis Kausalitas (Persamaan Struktural)}

Analisis estimation dikerjakan dngan cara menganalisis full-model untuk mengetahui hubungan kausalitas dan kecocokan model yang di bangun pada model yang akan diuji. Fullmodel di lakukan dengan cara menganti 2 anak panah korelasi dengan 1 anak panah yang menggambarkan hipotesis yang di berikan pada penelitian tersebut. Berikut ialah hasil estimation full-model yang ada pada penelitianini: 


\section{Gambar 3 Hasil Analisis SEM (Output Amos 25)}

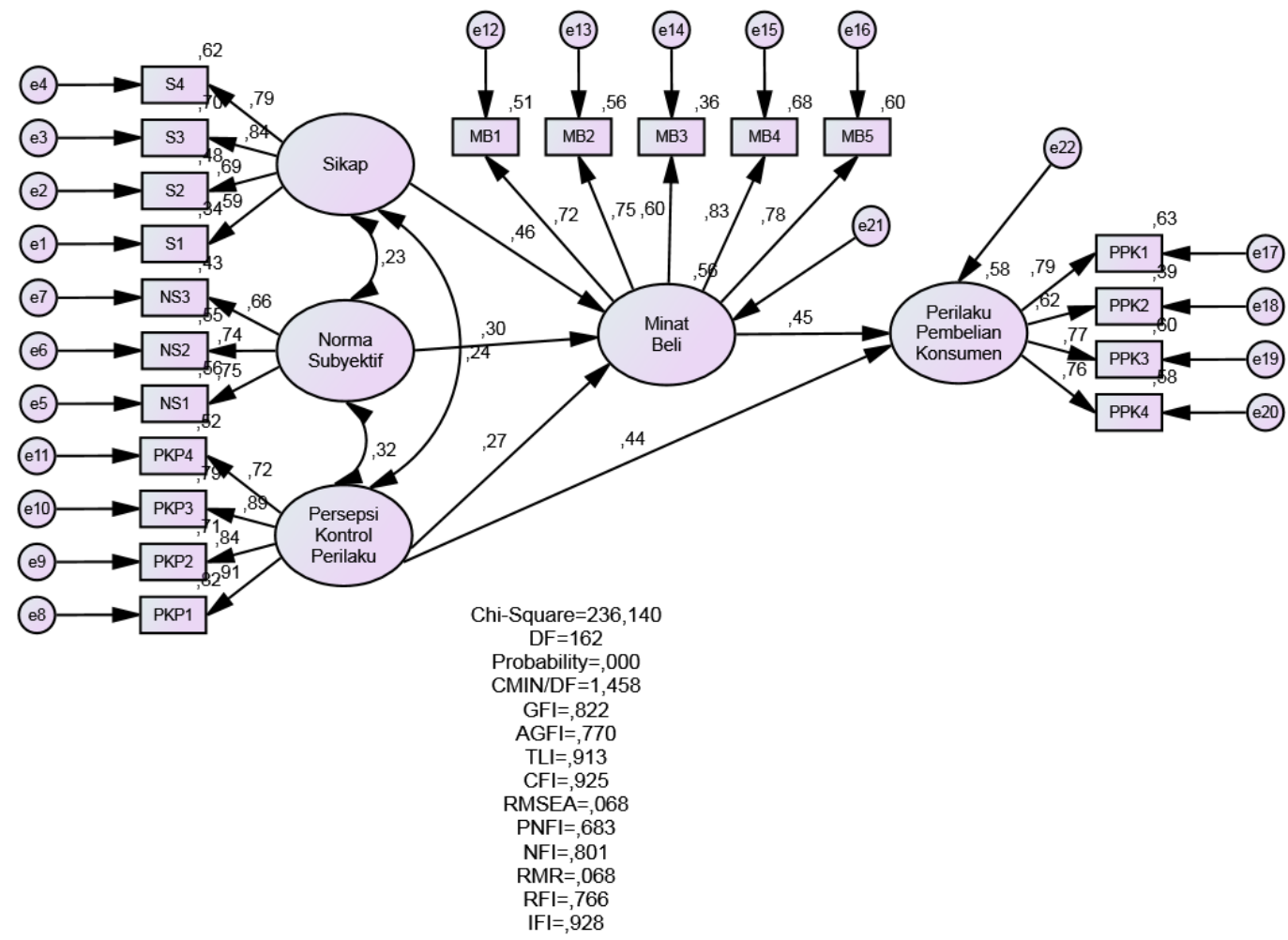

\section{Evaluasi Kriteria Ketepatan Model (Goodness of Fit Model)}

Pengujian kesesuaian model di evaluasi melalui uji terhadap berbagai kriteria-kriteria goodnessof-fit.Oleh sebab itu langkah pertama yang harus di lakukan ialah mengevalasi apkah data yang di gunakan pada penelitian ini dapat melengkapi asumsi-asumsi yang di perlukan dalam analisis SEM. Jika asumsi ini dapat dipenuhi, maka model penelitian ini bisa di uji. Beberapa pengukuran yang pntingdalam mengevaluasi kriteria-kriteria goodnessof-fit serta dengan nilai batas (cut-of value).

Dalam praktek penelitian secara empiris, seorang peneliti tidak harus memenuhi semua kriteria goodness of fit. Penggunaan 4 sampai dengan 5 kriteria goodness of fit dianggap sudah memadai untuk menilai kelayakan suatu model, asalkan masing-masing kelompok goodness of fit yaitu absolute fit indices (GFI, AGFI, Chi-Square, RMR dan RMSEA), incremental fit indices (NFI, NNFI, CFI, TLI dan parsimonious fit indices (PGFI dan PNFI) terwakili. Dengan demikian dapat dinyatakan bahwa dari hasil pengujian ini, model dapat digunakan, artinya secara empirik pengaruh sikap, norma subyektif dan persepsi kontrol perilaku terhadap minat beli dan perilaku pembelian konsumen adalah sesuai (fit) dengan model teoritisnya. 
Tabel 10 Hasil Uji Ketepatan Model

Tabel Uji Ketepatan Model (Goodness of Fit Model)

\begin{tabular}{|c|c|c|c|}
\hline Goodness of Index & Cut-off Value & Hasil Estimasi & Keterangan \\
\hline Chi-square $\left(\chi^{2}\right)$ & Diharapkan kecil & 236,140 & Bad fit \\
\hline Significance Probability $(p)$ & $\geq 0.05$ & 0,000 & Bad fit \\
\hline RMSEA & $\leq 0.08$ & 0,068 & Good fit \\
\hline GFI & $\geq 0.90$ & 0,822 & Marginal fit \\
\hline AGFI & $\geq 0.90$ & 0,770 & Marginal fit \\
\hline CMIN/DF & $2.00-5.00$ & 1,458 & Good fit \\
\hline TLI & $\geq 0.90$ & 0,913 & Good fit \\
\hline CFI & $\geq 0.90$ & 0,925 & Good fit \\
\hline NFI & $\geq 0.90$ & 0,801 & Marginal fit \\
\hline PNFI & $\geq 0.60$ & 0,683 & Good fit \\
\hline IFI & $\geq 0.90$ & 0,928 & Good fit \\
\hline RMR & RMR $<0.10$ & 0,068 & Good fit \\
\hline PGFI & PGFI $\geq 0.60$ & 0,634 & Good fit \\
\hline RFI & RFI $\geq 0.90$ & 0,766 & Marginal fit \\
\hline
\end{tabular}

Sumber: Data olahan Output Amos (2021)

\section{Uji Hipotesis}

Pengujian ini dilakukan dengan cara melihat critical-ratio pada regrssion-weight.

Berikut ialah uji hipotesis pada penelitian ini:

\section{Tabel 11 Hasil Uji Hipotesis Regression Weight}

Tabel Uji Hipotesis Regression Weights: (Group number 1 - Default model)

\begin{tabular}{|c|c|c|c|c|c|}
\hline & Estimate & S.E. & C.R. & $P$ & Label \\
\hline$<---$ & ,887 & 245 & 3,613 & $* * *$ & par_16 \\
\hline$<---$ NS & ,417 & 159 & 2,621 & 009 & par_17 \\
\hline <--- PKP & ,272 & , 100 & 2,737 & ,006 & par_18 \\
\hline PPK <--- MB & ,396 & ,108 & 3,677 & *** & par 19 \\
\hline PPK <--- & ,389 & ,095 & 4,075 & *** & par_20 \\
\hline
\end{tabular}

Sumber: Data olahan Output Amos (2021)

\section{Hipotesis 1 (Pengaruh Langsung Sikap Terhadap Minat Beli)}

Nilai c.r. antara pengaruh sikap terhadap minat beli adalah sebesar 3,613 dan nilai $p$ value $=0,000$. Dikarenakan nilai c.r lebih besar dari 1,96 $(3,613>1,96)$, dan nilai $p$-value kurang dari $\alpha(0,000<0,05)$. Dengan demikian dapat disimpulkan bahwa sikap berpengaruh positif signifikan terhadap minat beli.

\section{Hipotesis 2 (Pengaruh Langsung Norma Subyektif Terhadap Minat Beli)}

Nilai c.r. antara pengaruh norma subyektif terhadap minat beli adalah sebesar 2,621 dan nilai $p$-value $=0,009$. Dikarenakan nilai c.r lebih besar dari 1,96 $(2,621>1,96)$, dan nilai 
p-value kurang dari $\alpha(0,009<0,05)$. Dengan demikian dapat disimpulkan bahwa norma subyektif berpengaruh positif signifikan terhadap minat beli.

\section{Hipotesis 3 (Pengaruh Langsung Persepsi Kontrol Perilaku Terhadap Minat Beli)}

Nilai c.r. antara pengaruh persepsi kontrol perilaku terhadap minat beli adalah sebesar 2,737 dan nilai $p$-value $=0,006$. Dikarenakan nilai c.r lebih besar dari 1,96 (2,737 > 1,96), dan nilai $p$-value kurang dari $\alpha(0,006<0,05)$. Dengan demikian dapat disimpulkan bahwa persepsi kontrol perilaku berpengaruh signifikan terhadap minat beli.

\section{Hipotesis 4 (Pengaruh Langsung Minat Beli Terhadap Perilaku Pembelian Konsumen)}

Nilai c.r. antara pengaruh minat beli terhadap perilaku pembelian konsumen adalah sebesar 3,677 dan nilai $p$-value $=0,000$ Dikarenakan nilai c.r lebih besar dari 1,96 (3,677 > 1,96), dan nilai $p$-value kurang dari $\alpha(0,000<0,05)$. Dengan demikian ditarik kesimpulan minat beli berpengaruh positif signifikan terhadap perilaku pembelian konsumen.

\section{Hipotesis 5 (Pengaruh Langsung Persepsi Kontrol Perilaku Terhadap Perilaku Pembelian Konsumen)}

Nilai c.r. antara persepsi kontrol perilaku terhadap perilaku pembelian konsumen adalah sebesar 4,075 dan nilai $p$-value $=0,000$ Dikarenakan nilai c.r lebih besar dari 1,96 $(4,075>1,96)$, dan nilai $p$-value kurang dari $\alpha(0,000<0,05)$. Dengan demikian dapat disimpulkan bahwa persepsi kontrol perilaku berpengaruh positif signifikan terhadap perilaku pembelian konsumen.

\section{Besarnya Pengaruh Langsung (Direct Effect)}

Pengaruh langsung ditunjukkan dengan satu anak panah pada diagram dan sesuai dengan hipotesis yang diberikan. Berikut adalah pengaruh langsung pada model penelitian ini:

Tabel 12 Pengaruh Langsung (Direct Effect)

\begin{tabular}{|c|c|c|}
\hline & Minat Beli & $\begin{array}{c}\text { Perilaku } \\
\text { Pembelian Konsumen }\end{array}$ \\
\hline Sikap & 0,456 & - \\
\hline Norma Subyektif & 0,304 & - \\
\hline $\begin{array}{l}\text { Persepsi Kontrol } \\
\text { Perilaku }\end{array}$ & 0,274 & 0,440 \\
\hline Minat Beli & - & 0,446 \\
\hline
\end{tabular}

Sumber: Data olahan Output Amos (2021)

Berdasarkan tabel di atas dapat diketahui bahwa pengaruh langsung antara sikap terhadap minat beli sebesar 0,456; pengaruh norma subyektif terhadap minat beli sebesar 0,304 dan penagruh persepsi kontrol perilaku terhadap minat beli sebesar 0,274. 
Sedangkan pengaruh langsung persepsi kontrol perilaku terhadap perilaku pembelian konsumen sebesar 0,440 dan pengaruh antara minat beli terhadap perilaku pembelian konsumen adalah sebesar 0,446. Berdasarkan hasil analisis tampak bahwa pengaruh paling tinggi adalah sikap terhadap minat beli yakni sebesar 0,456.

\section{Pembahasan}

\section{Pengaruh Sikap Terhadap Minat Beli}

Sikap merupakan penilaian subjektif individu terhadap lingkungan sekitarnya, dan pengetahuan seseorang tentang diri sendiri maupun lingkungannya. Dari hasil penelitian ini terdapat pengaruh sikap terhadap minat beli produk kosmetik halal lip cream Wardah dengan diperolehnya nilai c.r lebih besar dari $1,96(3,613>1,96)$, dan nilai $p$-value kurang dari $\alpha$ $(0,000<0,05)$. Semakin tinggi keyakinan sikap para mahasiswa yang percaya terhadap produk kosmetik halal itu aman apabila digunakan mempengaruhi minat beli produk kosmetik halal secara online mahasiswa. Sikap mahasiswa yang percaya bahwa produk kosmetik halal lip cream Wardah itu aman digunakan dan memiliki manfaat ketika digunakan ini membuat mereka berminat untuk membeli kosmetik halal lip cream Wardah secara online.

Ini sejalan dengan penelitian terdahulu Alam dan Sayuti (2011) menyatakan bahwa sikap memiliki pengaruh yang signifikan dan positif terhadap minat beli. Penelitian ini menghasilkan bahwa sikap merupakan faktor penting dalam mempengaruhi pembelian produk makanan halal karena sikap positif yang tinggi tampaknya memiliki minat yang lebih besar untuk minat membeli produk makanan halal.

\section{Pengaruh Norma Subyektif Terhadap Minat Beli}

Norma subyektif merupakan sebuah tekanan sosial yang dirasakan setiap orang untuk memenuhi harapan orang lain agar melaksanakan atau tidak melaksanakan suatu perilaku. Norma subyektif juga merupakan sebuah motivasi seseorang untuk mematuhi pandangan orang yang dianggap penting bagi seseorang untuk melakukan atau pun menolak melakukan perilaku itu.

Dari hasil penelitian ini terdapat pengaruh positif signifikan Norma subyektif terhadap Minat beli produk kosmetik halal lip cream Wardah dengan diperolehnya nilai c.r lebih besar dari $1,96(2,621>1,96)$, dan nilai $p$-value kurang dari $\alpha(0,009<0,05)$. Minat beli kosmetik halal lip cream Wardah secara online pada mahasiswa ini dipengaruhi oleh norma yang ada pada mahsiswa itu, di mana mahasiswa itu mengikuti yang norma yang ada 
pada diri mahasiswa dan pengaruh orang-orang penting seperti keluarga maupun teman dekat mahasiswa itu.

Dengan mengikuti orang-orang yang dipercaya mahasiswa itu, mahasiswa tidak ragu untuk membeli produk lip cream Wardah ini. Implikasinya semakin banyak pengaruh dari orang-orang penting bagi mahasiswa untuk menggunakan produk lip cream Wardah maka minat beli produk lip cream Wardah semakin meningkat.

Hasil penelitian ini sejalan dengan penelitian terdahulu Rachbini (2018), norma subyektif memiliki pengaruh positif signifikan terhadap minat beli konsumen produk makanan halal di Jakarta. Ini menunjukkan bahwa norma subyektif sangat penting untuk minat beli seseorang.

\section{Pengaruh Persepsi Kontrol Perilaku Terhadap Minat Beli}

Persepsi kontrol perilaku merupakan keyakinan individu tentang keberhasilannya melakukan segala sesuatu, apakah tergantung pada usahanya sendiri atau faktor lain di luar dirinya. Persepsi kontrol perilaku pada seseorang seperti memiliki kemampuan, sumber daya dan pengetahuan tentang produk, ini yang akan mempengaruhi seseorang untuk melakukan suatu perilaku ataupun tidak sama sekali.

Dari hasil penelitian ini terdapat pengaruh positif signifikan Persepsi kontrol perilaku terhadap Minat beli produk kosmetik halal lip cream Wardah dengan diperolehnya nilai c.r lebih besar dari $1,96(2,737>1,96)$, dan nilai $p$-value kurang dari $\alpha(0,006<0,05)$. Ini menunjukkan bahwa apabila seseorang memiliki pengetahuan, sumber daya dan kemampuan untuk menggunakan produk kosmetik halal lip cream Wardah maka seseorang itu akan melakukan pembelian produk lip cream Wardah secara online. Mahasiswa sudah memiliki pengalaman dan pengetahuan tentang produk lip cream Wardah sehingga minat mahasiswa untuk membeli secara online akan tinggi, karena mahasiswa sudah percaya dengan produk ini.

Hasil penelitian ini sejalan dengan penelitian terdahulu Hajla (2017) persepsi kontrol perilaku dalam theory planned behavioral memiliki hubungan positif signifikan terhadap minat beli kosmetik halal seseorang di Saudi Arabia. Dan pada penelitian Soon (2017) persepsi kontrol perilaku konsumen muslim memiliki hubungan positif signifikan terhadap minat beli produk makanan halal. Persepsi kontrol perilaku yang ada pada konsumen muslim sangat berpengaruh terhadap minat beli produk mkanan halal pada penelitiannya.

\section{Pengaruh Minat Beli Terhadap Perilaku Pembelian Konsumen}


Minat beli merupakan sesuatu hal yang mewakili konsumen yang mempunyai kemungkinan, akan, rencana atau bersedia untuk membeli suatu produk atau layanan di masa yang akan datang. Dari hasil penelitian diatas terdapat pengaruh positif signifikan Minat beli terhadap Perilaku Pembelian konsumen produk kosmetik halal lip cream Wardah dengan diperolehnya nilai c.r lebih besar dari $1,96(3,677>1,96)$, dan nilai $p$-value kurang dari $\alpha$ $(0,000<0,05)$.

Semakin tinggi Minat beli kosmetik halal secara online mahasiswa itu maka akan semakin besar perilaku pembelian konsumen. Ketika minat seseorang mahasiswa untuk memiliki produk kosmetik halal yang aman dan ingin memilikinya, mahasiswa tidak raguragu untuk membeli nya secara online.

Mahasiswa Universitas Islam Riau tidak memiliki kendala dalam melakukan pembelian produk kosmetik lip cream Wardah ini secara online. Perilaku pembelian yang dilakukan oleh mahasiswa akan tetap mencari produk lip cream Wardah di internet ketika produk nya kosong dan menemukan alternatif-alternatif lainnya di internet. Dengan kemudahan mahasiswa mencari produk Wardah di internet, membuat mahasiswa mudah untuk melakukan pembelian produk wardah ini.

Hasil ini sejalan dengan penelitian Wee Chiew Shi et al. (2014) bahwa minat beli memiliki pengaruh positif signifikan terhadap perilaku pembelian konsumen sebenarnya pada produk makanan organik di Johor Malaysia.

\section{Pengaruh Langsung Persepsi Kontrol Perilaku Terhadap Perilaku Pembelian konsumen}

Persepsi kontrol perilaku merupakan keyakinan individu yang relatif stabil dalam segala situasi. Persepsi kontrol perilaku dapat berubah tergantung situasi dan jenis perilaku yang akan dilakukan. Persepsi kontrol perilaku ini memiliki pengaruh terhadap perilaku pembelian konsumen. Dari hasil penelitian ini terdapat pengaruh positif signifikan Persepsi Kontrol Perilaku terhadap Perilaku Pembelian konsumen produk kosmetik halal lip cream Wardah secara online dengan diperolehnya nilai c.r lebih besar dari 1,96 $(4,075>1,96)$, dan nilai $p$-value kurang dari $\alpha(0,000<0,05)$.

Ini menunjukkan bahwa kontrol perilaku seseorang yang mefasilitasi untuk langsung melakukan pembelian produk kosmetik halal lip cream Wardah secara online. Persepsi kontrol perilaku yang dimiliki mahasiswa tentang produk kosmetik halal itu membuat mahasiswa tidak ragu untuk membeli produk kosmetik halal langsung di internet. Semakin 
besar pengetahuan, kemampuan dan sumberdaya yang dimiliki mahasiswa itu maka semakin mahasiswa tidak ragu untuk langsung membeli produk kosmetik halal itu secara online.

Hasil ini tidak sejalan dengan penelitian Ajzen (2015) di mana persepsi kontrol perilaku tidak berpengaruh signifikan terhadap perilaku pembelian konsumen untuk mengkomsumsi suatu makanan. Di mana kontrol perilaku konsumen yang mempunyai kemampuan untuk mengkonsumsi makanan sesuai dengan kecukupan gizi tidak mau langsung untuk melakukan pembelian makanan yang memiliki gizi yang cukup. Tidak ada nya pengaruh yang signifikan ini karena konsumen ingin mengkonsumsi makanan sesuai selera nya dibandingkan memenuhi kebutuhan energi dan gizinya.

\section{KESIMPULAN}

Dari hasil penelitian mengenai "Analisis Pengaruh Planned Behavioral Lip Cream Kosmetik Wardah Terhadap Purchase Intention dan Consumer Buying Behavior Secara Online pada Mahasiswa Universitas Islam Riau”, dapat ditarik kesimpulan sebagai berikut:

1. Terdapat pengaruh positif dan signifikan mengenai pengaruh variabel sikap terhadap minat beli pada Mahasiswa Universitas Islam Riau.

2. Terdapat pengaruh signifikan mengenai pengaruh variabel norma subyektif terhadap minat beli pada Mahasiswa Universitas Islam Riau.

3. Terdapat pengaruh positif dan signifikan mengenai pengaruh variabel persepsi kontrol perilaku terhadap minat beli pada Mahasiswa Universitas Islam Riau.

4. Terdapat pengaruh signifikan mengenai pengaruh variabel minat beli terhadap perilaku pembelian konsumen pada Mahasiswa Universitas Islam Riau.

5. Tterdapat pengaruh signifikan mengenai pengaruh variabel persepsi kontrol perilaku terhadap perilaku pembelian konsumen pada Mahasiswa Universitas Islam Riau.

Bagi penelitian berikutnya disarankan sebagai berikut:

1. Pada penelitian berikutnya dapat memperluas sampel penelitian yang ada tidak hanya pada mahasiswa S1 tapi diperluas hingga mahasiswa D3, S2 dan S3 sehingga hasil penelitian nya dapat digeneralisasi.

2. Pada penelitian selanjutnya diharapkan dapat menambahkan variabel yang digunakan untuk mengetahui yang dapat mempengaruhi perilaku pembelian seseorang konsumen

3. Wardah meningkatkan jumlah dan jenis-jenis produk lip cream nya pada pasar online, karena banyak nya kalangan muda yang antusias dengan produk ini agar dapat meningkatkan penjualannya lagi. 
4. Pada peneliti selanjutnya yang ingin melakukan penelitian ini diharapkan melakukan wawancara langsung dengan para narasumber agar dapat memperkuat dan menggambarkan keadaan yang sesungguhnya.

\section{Keterbatasan Penelitian}

Penelitian ini masih banyak keterbatasan yang dialami ketika melakukan penelitian, diantaranya:

1. Hasil penelitian ini tidak dapat digeneralisasikan pada mahasiswa Universitas lainnya. Karena di Universitas Islam Riau hampir seluruh mahasiswa muslim, sehingga mengetahui halal suatu produk

2. Penelitian ini tidak melakukan metode wawancara karena pada saat pandemi Covid19 ini mahasiswa tidak melakukan kuliah secara tatap muka di kampus, sehingga peneliti sulit untuk bertemu secara langsung.

3. Variabel independen yang digunakan peneliti masih terbatas karena masih ada variabel independen yang bisa digunakan pada penelitian ini untuk mempengaruhi perilaku pembelian konsumen.

\section{DAFTAR PUSTAKA}

Ajzen, I., \& Fishbein, M. (1980). Understanding attitudes and predicting social behavior.

Ajzen, I. (1985). From intentions to actions: A theory of planned behavior. In J. Kuhl \& J. Beckman (Eds.), Action-control: From cognition to behavior (11-39). Germany, Springer Berlin Heidelberg.

Ajzen, I. and Fishbein, M. (1985), "The prediction of behavior from attitudinal and normative variables”, Journal of Experimental Social Psychology, Vol. 6, pp. 466-88.

Ajzen, I. (1991). Theory of planned behavior. Organizational behavior and human decision processes. $50(2)$

Ajzen, I. (2005). Attitude, Personality, and Behavior second edition. Open University Press: USA.

Alam, S. S., and Sayuti, N. M., 2011. Applying the theory of planned behavior in halal food purchasing. International Journal of Commerce and Management, 21(1), 8-20. Retrieved fiom Emerald Group Publishing Ltd.

Azmi, Aziz (2010). The Perception to Choose Halal Cosmetics Products: An Empirical Study for Malaysian Consumer. 6th International Conference on Business and 
Economics.

Blackwell, R.D., Paul, W.M. and James, F.E. (2006), “Attributes of attitudes”, Consumer Behavior, Thomson Press, New York, NY, pp. 235-43.

Abd Rahman, A., Asrarhaghighi, E., \& Ab Rahman, S. (2015). Consumers and halal cosmetic products: Knowledge, religiosity, attitude and intention. Journal of Islamic Marketing, 6(1), 148-163. https://doi.org/10.1108/JIMA-09-2013-0068

Determinants of Halal Purchase Intention: Case in Perlis. (2014). International Journal of Business and Social Research, 4(5), 118-123. https://doi.org/10.18533/ijbsr.v4i5.495

Hajla A.H. 2017. Why Do People Purchase Halal Cosmetics? An Integrated Model In Saudi Arabia. Journal of Arts, Science \& Commerce.

Khalek, A. A., \& Ismail, S. H. S. (2015). Why Are We Eating Halal - Using the Theory of Planned Behavior in Predicting Halal Food Consumption among Generation Y in Malaysia. International Journal of Social Science and Humanity, 5(7), 608-612. https://doi.org/10.7763/ijssh.2015.v5.526

Lada, S., Harvey Tanakinjal, G., \& Amin, H. (2009). Predicting intention to choose halal products using theory of reasoned action. International Journal of Islamic and Middle Eastern Finance and Management, 2(1), 66-76. https://doi.org/10.1108/175383909109 46276

Norafni, F. binti R., Shafii, Z., \& Shahwan, S. (2015). Awareness and Perception of Muslim Consumers on Halal Cosmetics and Personal Care Products. International Journal of Business, Economics and Management, 2(1), 1-14. https://doi.org/10.18488/journal.62/2 015.2.1/62.1.1.14

Nursalwani, M., Latiff Zulariff, A., Kelantan, M., \& Senior Lecturer, M. (2017). The Effect of Attitude, Subjective Norm and Perceived Behaviour Control Towards Intention of Muslim Youth at Public Universities in Kelantan to Consume Halal Labelled Chocolate Bar Product. Canadian Social Science, 13(2), 43-48. https://doi.org/10.3968/9278

Rachbini, Wirdato. 2018. The Relationship of Attitude, Subjective Norm, Perceived Behavioral Control on Halal Food Purchasing Behavior In Jakarta. Jakarta: IOSR Journal of Business and Management.

Schiffman, L.G. and Kanuk, L.L. 2007. Consumer Behavior. Prentice-Hall of India PrivateLimited, New Delhi. 
Soon J.M, Wallace. C. 2017. Application of theory of planned behaviour in purchasing intention and consumption of halal food. Nutrition \& Food Science, https://doi.org/10.1108/NFS-03-2017-0059

Sihombing, Umberto. 2004. Pengaruh Keterlibatan Dalam Pengambilan Keputusan, Penilaian pada Lingkungan Kerja dan Motivasi Berprestasi Terhadap Kepuasan Kerja Pamong Praja. http://www.dupdiknas.go.ig

Wee Chiew Shi et al. 2014. Consumers Perception, Purchase Intention and Actual Purchase Behavior of Organic food. Review of Integrative Business \& Economics Research. Vol 3(2). 